\title{
talenta
}

\section{Formulation and In-Vitro Penetration Test of Ketoconazole Nanoemulsion}

\author{
Ernoviya ${ }^{1}$ and Afriadi, ${ }^{2,3}$ \\ ${ }^{1}$ Department of Pharmacy, Health Polytechnic Ministry of Health, Medan, North Sumatera, \\ Indonesia. \\ ${ }^{2}$ Faculty of Pharmacy and Health, Institut Kesehatan Helvetia, Medan, Indonesia \\ ${ }^{3}$ Haji Adam Malik General Hospital Medan, Indonesia
}

\begin{abstract}
This study was aimed to formulate ketoconazole into nanoemulsion form and to compared the penetration ability of each formula with ketoconazole cream on the market as control. Formulation of nanoemulsion uses spontaneous methods and and also measurement of particle using the Particle Size Analyzer (PSA). In vitro penetration test used Franz diffusion cells. The results showed that nanoemulsion of each formula had different particle sizes, it was due to the distress of homogenizing two different systems, the duration and speed of stirring also affect the homogenity. The higher concentration of surfactant (tween 80) in the nanoemulation preparation could increasing the penetration ability of the preparation, but if the concentration exceeds the critical micelle concentration (CMC), a tight surfactant matrix (tween 80) will be formed which causes the release of ketoconazole to be slowed. Based on the observation, the highest penetration test was formula F3 as many as $4,268.01 \mu \mathrm{g} / \mathrm{cm}$.
\end{abstract}

Keywords: ketoconazole, nanoemulsion, penetration test

\begin{abstract}
Abstrak. Penelitian ini bertujuan untuk memformulasikan ketokonazol menjadi nanoemulsi dan membandingkan penetrasi masing masing formula serta dengan krim ketokonazol yang ada di pasaran. Pembuatan formula menggunakan metode nanoemulsi spontan dan pengukuran partikel menggunakan Particle Size Analyzer (PSA). Uji penetrasi secara in-vitro menggunakan sel difusi Franz. Hasil pengukuran partikel sediaan nanoemulsi menunjukkan bahwa masingmasing sediaan memiliki ukuran yang bervariasi, hal ini disebabkan sulitnya menghomogenkan dua sistem yang berbeda, selain itu beberapa faktor lain seperti lama maupun kecepatan pengadukan juga menyebabkan sediaan tidak homogen. Semakin tinggi konsentrasi surfaktan (tween 80) dalam sediaan nanoemulasi maka kemampuan penetrasi sediaan makin tinggi, tetapi apabila konsentrasinya melebihi konsentrasi misel kritis (KMK) maka akan terbentuk matriks surfaktan (tween 80) yang rapat dan menyebabkan pelepasan ketokonazol menjadi diperlambat. Hasil pengujian penetrasi tertinggi pada formula $F 3$ yaitu sebesar $4,268.01 \mu \mathrm{g} / \mathrm{cm}$.
\end{abstract}

Kata kunci: ketokonazole, nanoemulsi, uji penetrasi

Received 8 June 2020 | Revised 24 Juni 2020 | Accepted 3 July 2020.

\footnotetext{
*Corresponding author at: Department of Pharmacy, Health Polytechnic Ministry of Health, Medan, North Sumatera, Indonesia.

E-mail address: ernoviya 28@yahoo.com
}

Copyright (C 2020 Published by Talenta Publisher, Print ISSN : 2615-6199, Online ISSN : 2620-3731

Journal Homepage: https://talenta.usu.ac.id/index.php/idjpcr 


\section{Introduction}

Oral absorption of ketoconazole is not optimal because of its solubility and side effects, to overcome the shortcomings of this conventional system, a new drug delivery system is needed [1]. Topical ketoconazole available on the market today such as cream has side effects such as rashes, itching, irritation, pain, and redness, it is necessary to find out a new drug delivery systems such as nanoemulsion.

Nanoemulsion in topical form is a form of drug delivery for insoluble drugs given by increasing drug penetration through the skin[2]. Nanoemulsion consists of surfactants with or without other emulsifiers to increase stability, oils (natural / synthetic / semi-synthetic) and co-surfactants [3]. In vitro penetration studies are carried out to measure the speed and amount of compounds that pass through the skin, which depends on the drug, dosage form, excipients, penetration enhancing agents, and other formulation variables. One of the invitro method for measuring the amount of drug penetrated through the skin is using Franz diffusion cells. The membrane that used in this penetration test can be human skin or animal skin. The recent study was aimed to evaluate the penetration activity of ketoconazole nanoemulsion.

\section{Materials and Methods}

\subsection{Materials}

Ketoconazole (Kimia Farma), skin membrane (rabbit skin), pro analytics chemical solution puchased from PT. Merck (Germany) namely: Tween 80, Isopropyl myristate (IPM), Ethanol, Butyl Hydroxyl Toluene (BHT), Methylene Blue, NaCl, Potassium Dihydrogen Phosphate, Sodium hydroxide and Methanol.

\subsection{Preparation of nanoemulsion}

Preparation of nanoemulsion was using spontaneous emulsification method. Ketoconazole was added to the oil phase with BHT added, stirred until homogeneous, then add a smix solution which is a mixture of tween 80 and ethanol, then stirred using a magnetic stirrer until homogeneous. Distilled water are added by titration, stirring continuously until nanoemulsion is formed which is marked by the formation of a transparent (clear) solution [4]. Nanoemulsioan formula shows in table 1 . 
Table 1. Ketoconazole nanoemulsion formula

\begin{tabular}{lcccccc}
\hline No. & Formula & \multicolumn{5}{c}{ weight (gram) } \\
\cline { 3 - 7 } & & Ketoconazole & IPM & Ethanol & Tween 80 & BHT \\
$\mathbf{1}$ & F1 & 2 & 4.0 & 7.2 & 28.8 & 0.1 \\
$\mathbf{2}$ & F2 & 2 & 4.5 & 8.1 & 32.4 & 0.1 \\
$\mathbf{3}$ & F3 & 2 & 5.0 & 9.0 & 36.0 & 0.1 \\
$\mathbf{4}$ & F4 & 2 & 5.5 & 9.9 & 39.6 & 0.1 \\
$\mathbf{5}$ & F5 & 2 & 6.0 & 10.8 & 43.2 & 0.1 \\
\hline
\end{tabular}

\subsection{Organoleptic evaluation}

Observation of changes in color, odor, clarity, and phase separation.

\section{$2.4 \mathrm{pH}$ evaluation}

The final $\mathrm{pH}$ of the preparation is largely determined by the excipient used in the formulation, measurement using a digital $\mathrm{pH}$ meter. The preparation is weighed 1 gram and dissolved to $100 \mathrm{ml}$ distilled water, then the electrode is dipped in the solution, until the instrument shows a constant $\mathrm{pH}$ value [5]. The number shown in the $\mathrm{pH}$ meter is the $\mathrm{pH}$ value of the preparation.

\subsection{Viscosity evaluation}

Nanoemulsion viscosity was measured using a Brookfield viscometer at room temperature $\left(25^{\circ} \mathrm{C} \pm 2^{\circ} \mathrm{C}\right)[5]$.

\subsection{Determination of nanoemulsion type}

Determination of the type of nanoemulsion by dissolving in methylene blue. If the preparation is a type of oil in water, the color will dissolve and diffuse. If the preparation is a type of water in oil, methylene blue granules will be on the surface[6].

\subsection{Determination of Particle size and particle size distribution}

Particle size and distribution were measured using the SZ-100 particle size analyzer [6].

\subsection{Determination of the physical stability}

This test includes storage for 8 weeks at $4^{\circ} \mathrm{C} \pm 2{ }^{\circ} \mathrm{C}, 25^{\circ} \mathrm{C} \pm 2^{\circ} \mathrm{C}, 40^{\circ} \mathrm{C} \pm 2{ }^{\circ} \mathrm{C}$, centrifugation test at $3800 \mathrm{rpm}$ for 5 hours and also cycling test [6].

\subsection{In vitro penetration test}

In this study, skins were collected from male rabbits with a weight $1-1.25 \mathrm{~kg}$. Rabbit skin is cleaned of from attached fat, washed with distilled water, wrapped in aluminum foil, and stored immediately at $-50^{\circ} \mathrm{C}$. Franz-type diffusion cells with a receptor volume of $20 \mathrm{~mL}$ are used for drug penetration testing, solution of methanol-phosphate buffer of $10 \% \mathrm{v} / \mathrm{v}$ with $\mathrm{pH} 6.4$ is used as a receptor medium. Biological membrane from rabbit skin is cut and installed in Franz cells, with the 
side of the subcutaneous is facing up. A number of nanoemulsions are applied to biological membranes. The receptor compartment is filled with $10 \% \mathrm{v} / \mathrm{v}$ solution of methanol-buffer phosphate with $\mathrm{pH}$ of 6.4 , maintained the temperature at $37 \pm 0.5^{\circ} \mathrm{C}$ and stirring with magnetic stirrer. At a predetermined time interval $0.5 \mathrm{~mL}$ of receptor media is taken, put in a $5 \mathrm{~mL}$ volumetric flask and sufficient the volume to mark the line with a $10 \% \mathrm{v} / \mathrm{v}$ of methanol-phosphate buffer solution. Receptor media was immediately added with a $10 \% \mathrm{v} / \mathrm{v}$ of methanol- phosphate buffer solution with the same volume into the receptor compartment. This procedure is repeated for up to 12 hours. Samples were analyzed by UV spectrophotometer [7].

\subsection{Evaluation of Surface tension}

Surface tension measurements are carried out using a Du nouy Tensiometer. A total of $30 \mathrm{ml}$ of nanoemulsion solution was put into a cup and then placed on a measurement table [8].

\section{Results and Discussion}

\subsection{Organoleptic}

Formula F1, F2, F3, F4, and F5 have a soft yellow color, slightly viscous, transparent, homogeneous, and do not have phase separation. This shows that the concentration of oil (HDI), surfactant (Tween 80) and co-surfactant (Ethanol 96\%) used is appropriate. When applied to the skin, the formula dissolves easily and leaves a slightly sticky feel. This is because the Tween 80 concentration is high.

\section{$3.2 \mathrm{pH}$}

The $\mathrm{pH}$ of the desired formulation is in the skin $\mathrm{pH}$ range (4.5-6.5). $\mathrm{pH}$ should not be too acidic because it can irritate the skin, it must not be too alkaline because it can cause scaly skin [9]. All formulas made have a $\mathrm{pH}$ that is still in the $\mathrm{pH}$ range of the skin.

\subsection{Viscosity}

Viscosity measurement using a Brookfield viscometer. From the five formulas, it produces various viscosities. Based on the results of measurements with an increase in the concentration of oil in the formula, the concentration of tween 80 as a surfactant will also increase so that it will affect its viscosity. Increasing the concentration of tween 80 can reduce the size of globules. The reduced size of globules will increase the number of particles, which is associated with the efforts of the system to maintain a stable mass. Increasing the number of small globules will increase interactions between globules thereby increasing viscosity[10].

\subsection{Surface tension}

Measurement of surface tension on the five formulas shows that each has a varying surface tension.

The concentration of tween 80 in the preparation affects the surface tension, as shown in Figure 4.3, 
the higher the surfactant concentration in the preparation, the surface tension will decrease. Initially the surface tension drops slowly starting from formula F1 to F3, then drops rapidly from formulas F3 to F5 and then starts constant (F4 and F5), this is due to the achievement of the critical micelle concentration point (CMC). Some literature states that after reaching the marked critical micelle concentration (CMC) point with a rapid decrease in surface tension (drastic) and surface tension will still drop slightly or constant, because the formation of micelles runs very fast, so initially not only surfactant molecules in the aggregating system but also surfactant molecules on the surface of the system. While there are surface areas which are not occupied by surfactant molecules that cause surface tension to rise again, after this position is occupied again there will be no decrease in surface tension.

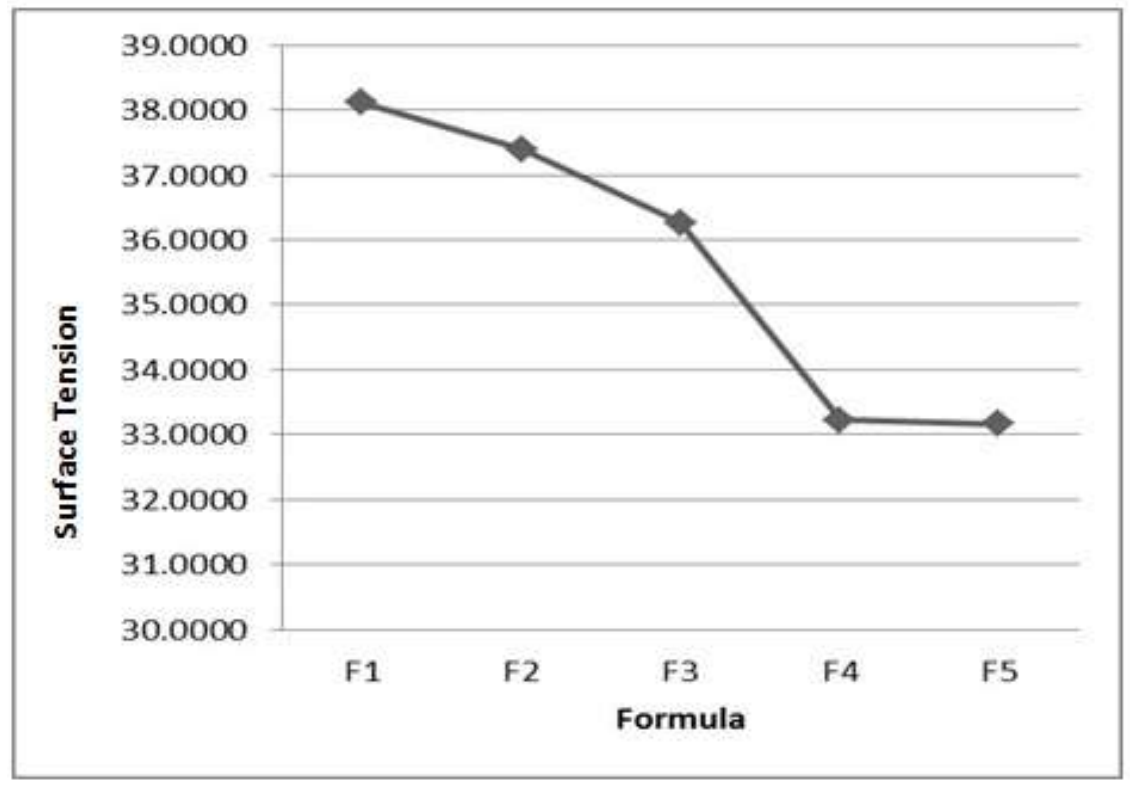

Figure 1. Surface tension measurement curve

\subsection{Nanoemulsion type}

All formulas have a nanoemulsion type of oil in water $(\mathrm{o} / \mathrm{w})$. This is because most of the components in the formula are hydrophilic or polar, although there are hydrophobic components, the nanoemulsion type is still oil in water $(\mathrm{o} / \mathrm{w})$. The results are as desired because oil-type nanoemulsions in water $(\mathrm{o} / \mathrm{w})$ are easily cleaned from the skin.

\subsection{Particle size and particle size distribution}

Measurements were conducted using a particle size analyzer (PSA) in the first week. Particle measurement results show that each formula has a varying size, this is due to the difficulty of homogenizing the two different systems, in addition to several other factors such as the duration or speed of stirring also causes the formula is not homogeneous. The particle size from the first week to the eighth week is increased, because most tween 80 underwent hydrolysis thereby reducing the 
effectiveness of the film layer of the nanoemulsion interface. Temperature modification during storage can cause a decrease in the effectiveness of the surfactant so that oil droplets tend to be close to one another and eventually produce larger droplets. The size distribution of globules is an important characteristic of the nanoemulsion system, because it can affect drug release and stability of preparations. The polydispersity index (PDI) is an indicator of the particle size distribution in the emulsion [11], the PDI value approaching zero indicates a mono-dispersion system and the PDI value approaching 1.0 which indicates that the emulsion has a very wide size distribution. Therefore, a PDI value lower than 0.2 indicates a homogeneous mixture, while a value of 0.3 indicates heterogeneity. The desired characteristic of the formulation is the high stability of the two components which do not mix to remain mixed as a single phase emulsion. An acceptable PDI value must be less than 0.7 depending on the type of sample. The results of this study indicate that the PDI values for F1 and F2 formulas are greater than 0.7 which means that both of these formulas have a broad particle size distribution (polydispersion) and include an unstable formula. PDI values for formulas F3 through F5 were below 0.7 so it were included in the polydispersion category and it were a stable formula category. The results of particle size measurements and globule size distribution from nanoemulsion formulas using PSA are shown in table 2.

Table 2. Particle measurement results and polydispersity index (PDI) values

\begin{tabular}{cccc}
\hline Formula & Particle size & Intensity & PDI \\
\hline F1 & 44.55 & 0.93 & 1.10 \\
& 250.57 & 0.07 & \\
F2 & 39.98 & 0.92 & 1.05 \\
& 234.49 & 0.07 & \\
F3 & 30.54 & 0.89 & 0.63 \\
& 64.58 & 0.12 & \\
& 9.10 & 0.07 & 0.68 \\
F4 & 17.43 & 0.58 & \\
& 58.86 & 0.38 & \\
& 4.78 & 0.08 & 0.68 \\
F5 & 12.99 & 0.61 & \\
& 50.03 & 0.21 & \\
\hline
\end{tabular}

\subsection{Physical Stability}

Storage at $4^{\circ} \pm 2^{\circ} \mathrm{C}$. All formulas were stable until the fifth week of storage. All formulas are stable during storage by cycling test and also during centrifugation test, all formulas are stable and there is no phase separation, which means that all formulas are stable to the gravitational force experienced for 1 year. 


\section{Conclusion}

The higher the concentration of the nanoemulsion-forming agent, especially surfactant (tween 80 ) in the preparation, the higher the penetration ability of the preparation, but if the concentration exceeds the critical micelle concentration, a tight surfactant matrix (tween 80) will be formed which causes the release of ketoconazole to be slowed. The highest penetration test results in the F3 formula is $4,268.01 \mu \mathrm{g} / \mathrm{cm}$

\section{Acknowledgement}

The author would like to thank the Faculty of Pharmacy, Universitas Sumatera Utara for supporting and providing this research work.

\section{REFERENCES}

[1]. R. Cristofoletti, N. A. Charoo, and J. B. Dressman, "Exploratory Investigation of the Limiting Steps of Oral Absorption of Fluconazole and Ketoconazole in Children Using an In Silico Pediatric Absorption Model," Journal of Pharmaceutical Sciences, vol. 105, no. 9, pp. 2794-2803, Sep. 2016.

[2]. M. Foldvari and P. Kumar, "Perspectives on Dermal Delivery of Macromolecular Drugs," Percutaneous Penetration Enhancers Drug Penetration Into/Through the Skin, pp. 355-358, 2017.

[3]. G. M. El Maghraby, "Occlusive Versus Nonocclusive Application in Transdermal Drug Delivery," Percutaneous Penetration Enhancers Drug Penetration Into/Through the Skin, pp. 27-33, 2017.

[4]. E. Ernoviya, M. Masfria, and K. Ramlan Sinaga, "Optimization And Evaluation Of Topical Ketoconazole Nanoemulsion," Asian Journal of Pharmaceutical and Clinical Research, vol. 11, no. 5, p. 143, May 2018.

[5]. J. L. Giongo, R. D. A. Vaucher, A. Ourique, Mí. Steffler, C. P. Frizzo, B. Hennemman, R. C. V. Santos, L. Q. S. Lopes, V. C. Rech, V. S. K. Nishihira, R. P. Raffin, P. Gomes, and M. Steppe, "Development Of Nanoemulsion Containing Pelargonium Graveolens Oil: Characterization And Stability Study," International Journal of Pharmacy and Pharmaceutical Sciences, vol. 8, no. 12, p. 271, Dec. 2016.

[6]. S. N. Kale and S. L. Deore, "Emulsion Micro Emulsion and Nano Emulsion: A Review," Systematic Reviews in Pharmacy, vol. 8, no. 1, pp. 39-47, Nov. 2016

[7]. S. K. Deore, R. K. Surawase, and A. Maru, "Formulation and Evaluation of O/W Nanoemulsion of Ketoconazole," Research Journal of Pharmaceutical Dosage Forms and Technology, vol. 11, no. 4, p. 269, 2019.

[8]. K. Gurpret and S. K. Singh, "Review of Nanoemulsion Formulation and Characterization Techniques," Indian Journal of Pharmaceutical Sciences, vol. 80, no. 5, 2018.

[9]. M. Kaufman, "Nanoemulsion Speeds Herpes Labialis Healing," Skin \& Allergy News, vol. 40, no. 5, p. 34, May 2009.

[10]. L. P. Guo, L. Wang, and Y. M. Zhang, "Applicability of Emulsion Viscosity Models to Crude Oil Emulsion,” Advanced Materials Research, vol. 581-582, pp. 50-53, Oct. 2012.

[11]. H. Zhang, Y. Liu, X. LI, and F. Yu, "Dual Latex Particle Size Distribution Of Concentrated Inverse Polymer Emulsion And Its Correlation With Stability," Acta Polymerica Sinica, vol. 011, no. 8, pp. 832-837, Aug. 2011. 